\title{
ANALISIS KEPUASAN KERJA PADA GURU DI SMK NEGERI 3 SINGARAJA (Sebuah Kajian Dari Perspektif Manajemen SDM)
}

\author{
D. Safhira1, I.N. Suarmanayasa² \\ Jurusan Manajemen, Universitas Pendidikan Ganesha, Singaraja \\ e-mail:deasafhira2@gmail.com, nengah.suarmanayasa@undiksha.ac.id
}

\begin{abstract}
Abstrak
Penelitian ini bertujuan untuk: (1) mendeskripsikan penyebab rendahnya kepuasan kerja, (2) mendeskripsikan dampak rendahnya kepuasan kerja, dan (3) mendeskripsikan upaya meningkatkan kepuasan kerja. Subjek penelitian ini adalah seluruh guru kontrak di SMK Negeri 3 Singaraja, dan objek penelitian adalah pada rendahnya kepuasan kerja.Populasi dalam penelitian ini yaitu semua informan yang akan memberikan informasi mengenai rendahnya kepuasan kerja yang dirasakan oleh guru kontrak, terdiri dari guru kontrak itu sendiri, kepala sekolah dan siswa di SMK Negeri 3 Singaraja. Penelitian ini termasuk kedalam penelitian deskriptif kualitatif. Penelitian ini menggunakan purposive sampling dan menggunakan teknik Snowball yang berguna untuk mencakup sampel yang lebih luas sebagai data pendukung. Temuan dari hasil penelitian ini menunjukan bahwa penyebab rendahnya kepuasan kerja yang dialami oleh guru kontrak disebabkan oleh beberapa faktor seperti kurangnya jam mengajar untuk guru kontrak JTM, keterlambatan pemberian gaji, serta mengajar tidak sesuai dengan kompetensi keahlian yang dimiliki.
\end{abstract}

Kata kunci: Guru, kepuasan kerja

\begin{abstract}
This study aims to: (1) describe the causes of low job satisfaction, (2) describe the impact of low job satisfaction, and (3) describe efforts to increase job satisfaction. The subjects of this research were all contract teachers at SMK Negeri 3 Singaraja, and the object of research was the low job satisfaction. The population in this study were all informants who would provide information about the low job satisfaction felt by contract teachers, consisting of the contract teachers themselves, the principal and students at SMK Negeri 3 Singaraja. This research is a qualitative descriptive study. This study uses purposive sampling and uses the Snowball technique which is useful for covering a wider sample as supporting data. The findings from the results of this study indicate that the causes of low job satisfaction experienced by contract teachers are due to several factors such as the lack of teaching hours for JTM contract teachers, delays in giving salaries, and teaching that is not in accordance with the competence of their skills.
\end{abstract}

Keywords: job satisfaction, teacher

\section{Pendahuluan}

Peran pendidikan sangatlah penting bagi setiap orang karena dapat menambah ilmu pengetahuan. Untuk merealisasikan tujuan pendidikan diperlukannya sosok yang bisa menjadi tumpuan proses pendidikan berlangsung. Guru adalah sosok yang diperlukan dalam merealisasikan tujuan tersebut. Guru adalah orang yang sangat penting. Tanpa adanya guru, akan sulit bagi sekolah untuk mencapai tujuan pendidikan. (Rahayuningsih, 2017) Terlepas dari tingkat penggunaan kurikulum di bidang pendidikan, guru tetap memegang peranan yang sangat penting dalam mencapai tujuan dari kurikulum tersebut. Sebagai tenaga pendidik, yang bertugas untuk mengajar, mendidik, membimbing, mengarahkan, melatih, dan menilai serta mengevaluasi peserta didik maka guru sangat dibutuhkan dalam dunia pendidikan. Sesuai dengan Undang-Undang No. 14 tahun 2005 tentang guru dan dosen Pasal 1 ayat 1 yang menerangkan bahwasanya guru ialah pendidik profesional yang tugas pokoknya adalah mendidik, mengajar membimbing, mengarahkan, melatih, menilai dan mengevaluasi peserta didik pada pendidikan anak usia dini, jalur pendidikan formal, pendidikan dasar dan pendidikan menengah.

Peran guru sangatlah penting serta tidak dapat diperbedakan baik guru yang telah 
bersertifikat ataupun guru yang belum bersertifikat. keduanya wajib bekerja secara profesional (Rahayu, 2017). Keberhasilan pendidikan ini dapat ditentukan dari profesionalitas guru dan kepuasan kerja mereka. Terdapat beberapa aspek yang dapat mempengaruhi keberhasilan sekolah untuk mencapai tujuan pendidikan. Salah satu aspeknya yaitu guru, dikarenakan langsung berkaitan dengan kegiatan pembelajaran di sekolah. Dalam hal ini guru diharapkan dapat memberikan hasil atau kontribusi yang sebesar-besarnya demi tercapainya tujuan dari pendidikan. Oleh karena itu, untuk mendukung sepenuhnya tujuan pendidikan tersebut maka kita harus memperhatikan kepuasan kerja guru. Menjaga kepuasan kerja guru sangat penting, karena akan mendorong guru tersebut supaya bekerja maksimal. Dengan memiliki semangat kerja yang tinggi bisa membantu organisasi ataupun sekolah secara efektif dan efisien untuk menggapai visi, misi dan tujuan yang diinginkan oleh sekolah.

Manajemen Sumber Daya Manusia bertanggung jawab untuk mengelola faktor manusia dengan tepat supaya mendapatkan tenaga kerja yang puas dengan pekerjaannya. Apabila guru tidak puas dengan pekerjaannya, motivasi guru akan menurun, tingkat kehadiran dan tingkat keterlambatan akan meningkat. Hal tersebut menunjukkan bahwasanya kepuasan kerja guru juga menjadi faktor penentu keberhasilan sekolah dalam mencapai tujuan pendidikan. Ketidakpuasan di tempat kerja dapat menimbulkan perilaku agresif, atau sebaliknya yaitu akan mengindikasikan sikap penarikan diri dari kontak dengan lingkungan sosialnya. Ketidakpuasan biasanya terkait dengan persyaratan, tuntutan dan keluhan pekerjaan tingkat tinggi. Pekerja dengan kepuasan kerja yang lebih rendah cenderung melakukan hal-hal pasif. Kepuasan kerja sangatlah berpengaruh bagi kelangsungan kegiatan organisasi di sekolah. Suatu organisasi atau perusahaan maupun sekolah dalam menjalankan aktivitas operasionalnya senantiasa mengharapkan tingkat kepuasan kerja yang maksimal agar dapat bekerja dengan optimal.

Tingkat kepuasan yang dimiliki setiap indivedu tentunya berbeda-beda sesuai dengan sistem penilaian yang terdapat pada dirinya sendiri. Semakin banyak aspek- aspek dalam pekerjaannya yang sesuai dengan keinginan individu tersebut, maka semakin tinggi juga tingkat kepuasan yang dirasakannya, pun sebaliknya jika semakin sedikit aspek-aspek dalam pekerjaannya yang sesuai dengan keinginan individu itu maka akan semakin rendah tingkat kepuasan yang dirasakannya. Kepuasan ini kadang kala sifatnya semu dan intristik, semu berarti apa yang dirasakan oleh manusia atas apa yang telah diperbuat hanyalah bersifat sementara atau sesaat saja. Kepuasan yang sesungguhnya adalah kepuasan yang dapat dirasakan setiap manusia setelah melakukan kegiatan sesuai dengan kewajibannya dan mendapatkan bayaran sesuai dengan harapan hati nuraninya. Kepuasan dasar ini dapat diperoleh, karena adanya dorongan dari hati nurani untuk melaksanakan kewajiban yang bersifat fisik serta dilandasi oleh keikhlasan untuk melakukan kewajiban tersebut.

Ketidakpuasan di tempat kerja dapat menimbulkan perilaku agresif dan sebaliknya, yang dapat mengindikasikan penarikan diri dari kontak dengan lingkungan sosial. (Wibowo, 2010). Maka dari itu kepuasan kerja karyawan harus terpenuhi agar karyawan merasa nyaman dan senang dalam bekerja. Berkaitan dengan masalah kepuasan kerja maka penelitian ini dilakukan di SMK Negeri 3 Singaraja. Sekolah ini merupakan sekolah menengah kejuruan yang memiliki 10 jurusan. SMK Negeri 3 Singaraja memiliki 190 orang guru yang terdiri dari guru PNS dan guru kontrak, guru kontrak disini terbagi menjadi dua yakni guru kontrak dengan kontrak maksimal dan guru kontrak JTM (Jam Tatap Muka) dimana, guru kontraknya banyak yang merasakan kurangnya kepuasan kerja.

Setiap organisasi atau perusahaan pada umumnya mengharapkan para karyawannya mampu melaksanakan tugas dengan baik, hal ini bertujuan supaya perusahaan mempunyai sumber daya manusia yang berkualitas sekaligus memiliki daya saing yang tinggi. SMK Negeri 3 Singaraja memiliki visi yaitu "Terwujudnya tamatan yang berkompetensi global berbasis keunggulan lokal dan lingkungan hidup“. Dan misinya yaitu : (1) Melangsungkan pembelajaran yang efektif berstandar kompetensi nasional dan global berbasis keunggulan lokal. (2) Menumbuhkembangkan Semangat berkompetisi secara sehat dalam prestasi akademik dan non akademik. (3) Menghasilkan tamatan yang kompeten dan berbudi pekerti luhur. (4) Menciptakan lingkungan sekolah berwawasan wiyata mandala. Adapun tujuan 
sekolah yaitu : (1) Menyiapkan peserta didik agar menjadi manusia produktif (2) Mampu bekerja mandiri, mengisi lowongan pekerjaan yang ada di DU/DI sebagai tenaga kerja tingkat menengah sesuai dengan kompetensi pada kompetensi yang dipilihnya (3) Menyiapkan peserta didik agar mampu memilih karir, ulet dan gigih dalam berkompetisi (4) Mempersiapkan peserta didik dengan ilmu pengetahuan, teknologi dan seni untuk mengembangkan diri secara mandiri ataupun melalui pendidikan tinggi.

Berdasarkan pengamatan pada saat melakukan observasi awal mengenai kepuasan kerja, menunjukan bahwa kepuasan kerja pada guru kontrak masih rendah. Rendahnya kepuasan kerja ini paling sering dirasakan oleh guru kontrak. Diduga rendahnya kepuasan kerja pada guru kontrak karena seringnya mengalami keterlambatan pemberian gaji yang cukup lama hingga berbulan-bulan, selain itu yang menyebabkan kurangnya kepuasan kerja dikarenakan kurangnya ruang kerja yang tersedia untuk para guru, kemudian kurangnya jam mengajar yang diberikan, serta kurangnya apresiasi yang diberikan untuk guru yang berprestasi. Permasalahan tersebut merupakan indikasi adanya masalah pada tingkat kepuasan kerja guru di SMK Negeri 3 Singaraja.

Rendahnya kepuasan kerja ini dapat menyebabkan menurunnya semangat mengajar yang dapat membuat rasa malas untuk mengajar, lalu dengan sengaja terlambat datang saat akan mengajar dan malas untuk berpartisipasi dalam mengikuti kegiatan yang ada di sekolah. Sedangkan pada guru tetap (guru PNS) merasakan kepuasan kerja yang cukup, dikarenakan guru tetap tidak pernah mengalami keterlambatan pemberian gaji, serta guru tetap juga mendapatkan banyak tunjangan seperti mendapat insentif dan tunjangan- tunjangan lainnya.

Berdasarkan latar belakang penelitian maka judul yang diangkat dalam penelitian ini ialah Analisis Kepuasan Kerja Pada Guru Di SMK Negeri 3 Singaraja. Menjaga kepuasan kerja guru sangatlah penting, karena akan mendorong guru tersebut untuk bekerja dengan semangat kerja yang tinggi dan pada akhirnya dapat membantu sekolah secara efektif dan efisien dalam mencapai tujuan yang diinginkan. Jadi diharapkan para guru merasa cukup dan terpenuhi akan kepuasan kerjanya guna memperoleh kinerja yang baik.

\section{Metode}

Riset ini termasuk kedalam penelitian deskriptif dengan pendekatan kualitatif. Metode ini merupakan kajian yang menggunakan presepsi serta bahan-bahan tertulis untuk mengetahui hal-hal yang tidak bisa terukur dengan pasti (intangible). Metode penelitian yang digunakan guna mendapatkan pengetahuan yang lebih luas terhadap objek penelitian pada suatu masa tertentu (Hidayat, 2010). Penelitian deskriptif ialah riset yang bertujuan untuk memaparkan atau mendeskripsikan suatu keadaan, peristiwa, objek baik itu seseorang maupun segala sesuatu yang berhubungan varibel-variabel tersebut yang bisa dijelaskan baik dengan angka maupun kata-kata (Setyosari, 2010) .

Subjek penelitian yaitu seluruh guru kontrak di SMK Negeri 3 Singaraja. Sedangkan objek penelitian adalah pada rendahnya kepuasan kerja. Penelitian ini dilakukan Di SMK Negeri 3 Singaraja yang beralamatkan di Jl Gempol, Banyuning, Singaraja. Dikarenakan terjadi rendahnya kepuasan kerja pada guru kontrak, sehingga peneliti melakukan penelitian ini guna menemukan faktor yang menyebabkan rendahnya kepuasan kerja pada guru kontrak tersebut. Adapun waktu penelitian dilakukan selama 7 bulan, dimulai dari bulan Januari 2020 sampai dengan bulan Juli 2020.

Jenis data yang digunakan dalam riset ini ialah data kualitatif yaitu berupa alasan mengapa terjadi rendahnya kepuasan kerja pada guru kontrak, dampak dari rendahnya kepuasan kerja dan upaya untuk menanggulangi rendahnya kepuasan kerja yang dialami guru kontrak. Sumber data ini diperoleh dari SMK Negeri 3 Singaraja dan juga dari seluruh guru kontrak di SMK Negeri 3 Singaraja. Menyusun instrumen adalah langkah penting dalam pola prosedur penelitian. Instrumen berperan sebagai alat bantu dalam mengumpulkan data yang diperlukan. Bentuk instrumen berkaitan dengan metode pengumpulan data, misal metode wawancara yang instrumennya pedoman wawancara. Metode angket atau kuesioner, instrumennya berupa angket atau kuesioner (Siyoto, 2015). Peneliti menjadi instrument dalam 
penelitian ini, dari penetapan fokus penelitian, memilih informan sebagai sumber data, melakukan pengumpulan data, menilai kualitas data, dan analisis data.

Dalam penelitian kualitatif, yang disebut sebagai populasi adalah situasi yang terjadi pada sekolah, guru dan siswa di SMK Negeri 3 Singaraja. Sampel data dipilih melalui purposive sampling. Pemilihan sekelompok subjek dalam purposive sampling berdasarkan pada karakteristik tertentu yang dilihat dapat menyandang serta berkaitan erat dengan karakteristik populasi yang sudah diketahui sebelumnya. Dengan kata lain, sesuaikan unit sampel yang bersentuhan dengan standar-standar tertentu yang ditentukan sesuai dengan tujuan penelitian atau permasalahan penelitian. Peneliti akan mengamati aktivitas orang-orang yang berada pada suatu tempat tertentu yang menjadi objek penelitian.

Populasi dalam penelitian ini ialah semua informan yang akan memberikan informasi mengenai rendahnya kepuasan kerja yang dirasakan oleh guru kontrak , yang terdiri dari guru kontrak itu sendiri, kepala sekolah dan siswa di SMK Negeri 3 Singaraja. Dalam penelitian ini menggunakan purposive sampling dan menggunakan teknik Snowball yang berguna untuk mencakup sampel yang lebih luas sebagai data pendukung.

Adapun teknik pengumpulan data yang digunakan dalam penelitian ini adalah 1) Observasi Partisipasi. Observasi adalah teknik pengumpulan data dimana peneliti terjun secara langsung ke objek yang diteliti untuk memperoleh data berupa kenyataan yang terdapat di lapangan seperti mencatat data-data jumlah guru yang ada. 2) Wawancara Mendalam. Wawancara adalah teknik pengumpulan data dengan melakukan Tanya jawab secara langsung dengan narasumber. Dalam penelitian ini, peneliti melakukan Tanya jawab atau wawancara dengan guru kontrak, guru tetap (PNS), kepala sekolah dan siswa di SMK Negeri 3 Singaraja. Pedoman wawancara merupakan instrumen pendukung yang akan digunakan dalam metoda wawancara. 3) Dokumentasi. dokumentasi yaitu metode pengumpulan data melalui dokumen yang tersedia berupa catatan yang tersimpan dengan baik atau di dokumentasikan sebagai bahan dokumen. Melalui studi dokumentasi diharapkan menjadi pelengkap dari metode wawancara mendalam dan observasi. 4)Triangulasi. Triangulasi merupakan teknik pengumpulan data yang bersifat menggabungkan dari berbagai teknik pengumpulan data yang telah ada.

Analisis data penelitian kualitatif dan deskriptif, yaitu penelitian dilakukan pada saat pengumpulan data dan setelah pengumpulan data selesai dalam jangka waktu tertentu. Miles dan Huberman Sugiyono (2014: 246-253) mengungkapkan bahwa kegiatan analisis data kualitatif dilakukan secara interaktif terus menerus dan berlanjut hingga selesai, sehingga menjenuhkan data. Aktivitas dalam analisis data, yaitu : a) Reduksi Data. Jika semakin lama peneliti menghabiskan waktunya dilapangan, maka jumlah datanya akan menjadi semakin kompleks. Untuk itu harus segera dilakukan analisis data dengan cara mereduksi data. Mereduksi data berarti meringkas, meneliti konten utamanya, memusatkan pada hal-hal yang penting , mencari tema dan polanya. b) Data Display. Dalam penelitian kualitatif, data dapat dipresentasikan dalam bentuk uraian singkat, diagram, hubungan antar kategori, flowchart, dan sejenisnya. Teks naratif biasanya digunakan untuk menyampaikan data dalam penelitian kualitatif. Dalam hal ini, peneliti akan mengkaji data dalam bentuk teks, untuk memperjelas hasil penelitian maka dengan menyertakan tabel atau gambar supaya dapat membantu penelitian. c) Conclusion Drawing/Veryvication. Simpulan dalam riset kualitatif ini bisa jadi memperoleh Jawaban atas rumusan sudah dirumuskan sejak awal, namun bisa jadi bukan karena soal dan rumusan masalah dalam penelitian kualitatif masih bersifat sementara dan akan berkembang setelah dilakukan penelitian di lapangan. Kesimpulan dari penelitian kualitatif adalah penemuan baru yang belum pernah terjadi sebelumnya. Temuan tersebut dapat berupa uraian ataupun uraian tentang objek yang sebelumnya yang redup atau tidak jelas sehingga menjadi jelas setelah diteliti, dan dapat berupa kausalitas atau interaksi.

Untuk menguji keabsahan data, maka perlu dilakukan uji validitas data. Uji validitas adalah ketepatan tafsiran yang dibuat dari hasil penilaian atau evaluasi. Atau uji validitas merupakan uji derajat ketepatan antara data yang dilaporkan dengan kenyataan dilapangan. Uji validatas yang dilakukan dalam riset ini adalah uji kreadibilitas. Uji kreadibilitas data merupakan pengujian kepercayaan terhadap data hasil penelitian. 
Cara pengujian dilaksanakan dengan perpanjangan pengamatan, meningkatkan ketekunan dalam penelitian, triangulasi, diskusi dengan teman sejawat, dan analisis kasus negatif. a.)Meningkatkan ketekunan. Meningkatkan ketekunan berarti melakukan pengamatan secara lebih cermat dan berkesinambungan. Dengan cara tersebut determinisme data dan urutan kejadian dapat direkam secara deterministik dan sistematis. b) Pemeriksaan teman sejawat melalui diskusi. Teknik ini dilakukan dengan menunjukan hasil sementara dalam bentuk diskusi dengan pembimbing, penguji dan teman sejawat. c) Analisis kasus negative. Kasus negatif ialah kasus yang tidak sesuai atau berbeda dengan hasil penelitian hingga pada saat tertentu. Melakukan analisis kasus negatif berarti mencari data yang berbeda atau mungkin bertentangan dengan data yang sudah ditemukan. d) Triangulasi. Triangulasi dalam pengujian kreadibilitas diartikan sebagai pemeriksaan data dengan beragam metode serta sumber perolehan data. Bila data yang didapatkan sama, maka data tersebut dapat dikatakan kredibel. Dalam peneliitan ini teknik triangulasi yang dilakukan dengan cara mengajukan pertanyaan yang sama pada setiap sumber.

\section{Hasil dan pembahasan}

Riset yang telah dilakukan terkait kepuasan kerja ini dapat ditemukan faktor-faktor penyebab dari rendahnya kepuasan kerja yang dialami oleh guru kontrak di SMK Negeri 3 Singaraja. Adapun faktor penyebab tersebut dapat dilihat pada tabel 1 kemudian dampak rendahnya kepuasan kerja dapat dilihat pada tabel 2 dan upaya yang dilakukan untuk meningkatkan kepuasan kerja dapat dilihat pada tabel 3

Berikut ini adalah tabel 1 yang menjelaskan faktor-faktor penyebab dari rendahnya kepuasan kerja yang dialami oleh guru kontrak di SMK Negeri 3 singaraja.

Tabel 1. Penyebab Rendahnya kepuasan kerja pada guru kotrak di SMK Negeri 3 Singaraja

\begin{tabular}{ll}
\hline \multicolumn{1}{c}{ Faktor Penyebab } & \multicolumn{1}{c}{ Temuan Penelitian } \\
\hline Jam Mengajar & Masih banyak guru kontrak yang mendapatkan jam \\
& mengajar kurang dari standar, yang seharusnya 24 jam \\
& mengajar. Hal ini dikarenakan jam mengajar tersebut \\
& difokuskan untuk guru PNS terlebih dahulu \\
Gaji & Sering mengalami keterlambatan pemberian gaji \\
Kompetensi Keahlian & Terdapat guru yang mengajar tidak sesuai dengan \\
& kompetensi keahlian yang dimiliki, dikarenakan ada \\
& penghapusan beberapa mata pelajaran yang membuat \\
& guru tersebut harus mengajar sesuai mata pelajaran yang \\
& tersedia.
\end{tabular}

Adapun dampak dari rendahnya kepuasan kerja pada guru kontrak tersebut yakni seperti pada table 2 sebagai berikut:

Tabel 2. Dampak Rendahnya kepuasan kerja

\begin{tabular}{ll}
\hline \multicolumn{1}{c}{ Aspek } & \multicolumn{1}{c}{ Temuan Penelitian } \\
\hline Guru Kontrak & $\begin{array}{l}\text { 1. Terdapat intensitas mengajar yang tidak sungguh- } \\
\text { sungguh di kalangan guru kontrak }\end{array}$ \\
& $\begin{array}{l}\text { 2. Guru kontrak kurang memiliki minat dalam berpartisipasi } \\
\text { kegiatan sekolah }\end{array}$ \\
Siswa & $\begin{array}{l}\text { Siswa tidak mendapatkan pembelajaran yang berkualitas } \\
\text { Sekolah }\end{array}$ \\
Masyarakat & $\begin{array}{l}\text { San tujuannya mengalami kesulitan dalam mencapai visi, misi } \\
\text { Kualitas tenanga pengajar kontrak menjadi pertimbangan } \\
\text { bagi orang tua yang ingin menyekolahkan anak anaknya di } \\
\text { SMK Negeri 3 Singaraja }\end{array}$ \\
\hline
\end{tabular}


Adapun upaya yang dilakukan untuk meningkatkan kepuasan kerja pada guru yakni dapat dilihat pada table 3 berikut :

Tabel 3. Upaya yang dilakukan oleh SMK Negeri 3 Singaraja untuk meningkatkan kepuasan kerja pada guru kontrak.

\begin{tabular}{|c|c|}
\hline Aspek & Temuan Penelitian \\
\hline Kebutuhan ATK & $\begin{array}{l}\text { Sekolah selalu menyediakan ATK Untuk Kepperluan guru } \\
\text { dan kepentingan mengajar. }\end{array}$ \\
\hline Internet & $\begin{array}{l}\text { Sekolah Memasang jaringan internet di seluruh ruangan yang } \\
\text { ada disekolah guna memperlancar proses belajar mengajar }\end{array}$ \\
\hline Lingkungan & $\begin{array}{l}\text { Lingkungan memberikan fasilitas berupa tempat yang aman } \\
\text { dan nyaman. }\end{array}$ \\
\hline Pelatihan & $\begin{array}{l}\text { Sekolah memberikan fasilitas pelatihan kepada guru agar } \\
\text { dapat mengajar secara maksimal. }\end{array}$ \\
\hline Reward & $\begin{array}{l}\text { Sekolah memberikan penghargaan kepada guru dalam } \\
\text { bentuk apresiasi kedalam sosial media dan pengumuman } \\
\text { kepada seluruh warga SMK Negeri } 3 \text { Singara. }\end{array}$ \\
\hline
\end{tabular}

Berdasarkan Tabel 1, maka diperoleh hasil penelitian mengenai penyebab terjadi rendahnya kepuasan kerja pada guru kontrak di SMK Negeri 3 Singaraja. Rendahnya kepuasan kerja ini terjadi dikarenakan beberapa faktor seperti, jam mengajar yang kurang, keterlambatan pemberian gaji serta tenaga pengajar yang mengajar tidak sesuai dengan kompetensi keahliannya. Berdasarkan hasil wawancara yang telah dilakukan oleh peneliti ditemukan bahwa penyebab rendahnya kepuasan kerja yang dialami oleh guru kontrak yakni adalah (1) Jam Mengajar, (2) Gaji, (3) Kompetensi keahlian.

(1) Jam mengajar. Tahun Ajaran 2017/2018, berdasarkan Peraturan Menteri Pendidikan dan Kebudayaan (Permendikbud) Nomor 23 Tahun 2017 tentang Hari Sekolah. Guru diwajibkan memenuhi ketentuan beban kerja 40 jam per minggu. Ketentuan ini Permendikbud menyebutkan, bahwasanya para guru harus menanggung beban kerja dalam proses penerapan aturan hari sekolah, hari sekolah menetapkan 40 jam, lima hari dalam satu minggu.

Direktur Jenderal Pendidikan Dasar dan Menengah (Dikdasmen), Kementerian Pendidikan dan Kebudayaan (Kemendikbud) menjelaskan, dengan kewajiban ini, beban kerja guru tidak hanya sekadar tatap muka, melainkan seluruh komponen beban kerja dihitung dalam delapan jam per hari. yang sudah diatur dalam Peraturan Pemerintah (PP) Nomor 19 tahun 2017 yang merevisi PP Nomor 74 tahun 2008 tentang Guru.

Komponen beban kerja yang seluruhnya dihitung mulai dari merencanakan pembelajaran, melaksanakan pembelajaran, menilai hasil pembelajaran, membimbing dan melatih peserta didik, hingga melaksanakan tugas tambahan yang melekat pada pelaksanaan kegiatan pokok. Ketentuan pelaksanaan beban kerja 40 jam per minggu itu berlaku baik bagi guru yang bekerja di sekolah yang telah melaksanakan ketentuan Permendikbud Nomor 23 Tahun 2017 (lima hari per minggu) maupun guru yang bekerja di sekolah yang belum melaksanakan ketentuan tersebut (enam hari per minggu).

Faktor penyebab rendahnya kepuasan kerja dikarenakan guru kontrak kekurangan jam mengajar, hal ini karena jam mengajar diutamakan untuk guru PNS agar mendapatkan 24 jam mengajar. Sehingga guru kontrak yang ada di SMK Negeri 3 Singaraja hanya mendapatkan sisa dari jam mengajar yang tersisa. kurangnya jam mengajar yang diberikan kepada guru kontrak inilah yang meneyebabkan upah atau gaji yang diberikan tidak sesuai karena upah atau gaji yang diberikan itu berdasarkan dengan jam mengajar. Seperti yang dikatakan oleh Bapak Wayan Adi Perbawa, S.sos (21, Juli 2020 Selaku Guru PNS.

"Jam Mengajar kalau untuk Guru yang PNS pasti sudah sesuai, tapi untuk guru kontrak itu menyesuaiakan, karena jam mengjar untuk guru kontrak itu sisa dari jam guru PNSnya" 
(2) Gaji. Kementerian Pendidikan dan Kebudayaan Republik Indonesia menerbitkan Peraturan Menteri Pendidikan dan Kebudayaan Republik Indonesia (No. 8 Tahun 2017, Petunjuk Teknis Bantuan Penyelenggaraan Sekolah). Salah satu poin utama dalam Permendikbud adalah dana bantuan operasional sekolah (BOS) yang telah tersedia untuk membiayai guru honorer di SMA / SMK seluruh Indonesia. Oleh karena itu, per 27 Februari 2017, remunerasi guru sudah memiliki dasar hukum, dan mereka bisa mendapatkan gaji rutin dari dalam negeri melalui dana BOS yang didapatkan oleh sekolah. Sebanyak 15 persen anggaran dana BOS yang diterima sekolah bisa digunakan untuk guru honorer di SMA dan SMK Negeri.

Berdasarkan hasil wawancara yang dilakukan, ditemukan hasil penelitian bahwa penyebab rendahnya kepuasan kerja yang dirasakan dikarenakan sering mengalami keterlambatan pemberian gaji yang cukup lama kepada guru kontrak. Keterlambatan pemberian gaji ini disebabkan karena lamanya proses penyetoran data gaji kepusat, dan sekolah menunggu kembali dana tersebut turun dari pusat. Kemudian juga gaji disesuaikan dengan jam mengajar jadi hal ini menyebabkan banyak guru kontrak yang gajinya tidak sesuai dengan harapan akibat dari kurangnya jam mengajar. Hal ini diutarakan oleh ibu Ketut Kartika Sari Dewi, S.Pd (21, Januari 2020) Selaku Guru.

"Untuk Gaji Sudah Sesuai, hanya saja sering sekali terlambat pemberian gajinya" Hal yang sama diutarakan oleh Ibu Ida Ayu Putu Mas Septiantini, S.Pd pada (21, Januari 2020) selaku guru kontrak.

"Gaji pastinya sesuai dengan jam megajar tetapi untuk pemberiannya sering sekali terlambat cukup lama "

(3) Tidak Sesuai Kompetensi Keahlian, Terdapat beberapa guru yang mengajar tidak sesuai dengan kompetensi keahlian yang dimilikinya, Hal tersebut dikarenakan adanya mata pelajaran yang dihapuskan sehingga guru harus mengajar mata pelajaran yang tidak sesuai dengan kompetensi keahliannya. Hal ini membuat guru kontrak tersebut perlu belajar kembali serta mengikuti pelatihan-pelatihan dan memantapkan pembelajaran yang akan diberikan kepada siswanya. Akibat dari permasalahan tersebut guru kontrak mengeluhkan dirinya dikarenakan banyak waktu yang terbuang dan guru konrak tersebut merasa terbebani karena harus memulai hal baru yang tidak sesuai dengan bidang komptensinya. Seperti yang diutarakan oleh ibu Luh Dita Widiastuti, S.Pd. (Selasa, 21 Juli 2020) selaku guru kontrak di SMK Negeri 3 Singaraja.

"Karena ada mata pelajaran yang dihapuskan dan agar tetap mendapatkan jam mengajar maka saya mengajar mata pelajaran yang berbeda dari bidang saya. Dan agar bisa mengetahui dasar mata pelajaran yang bukan bidang saya ini saya harus mengikuti pelatihan agar dapat mengajar dan cukup sulit untuk mengikutinya karena benar-benar mempelajari dari awal"

Dari hasil wawancara yang telah dilakukan ini, maka dapat disimpulkan bahwa mengajar tidak sesuai dengan kompetensi yang diberikan akan mengakibatkan penurunan kepuasan kerja pada guru. Serta diharapkan pula alasan dari guru kontrak tersebut bertahan di SMK Negeri 3 Singaraja dapat membuat guru tersebut meningkatkat kinerjanya.

Serta adapun alasan mengapa guru kontrak tersebut tetap bertahan menjadi guru kontrak di SMK Negeri 3 Singaraja, yakni karena agar tetap adanya pemasukan untuk guru tersebut untuk mencukupi kebutuhan hidupnya, karena bagi sebagian guru kontrak tersebut tidak ada lagi pekerjaan lain yang bisa dilakukan untuk tetap memenuhi kebutahanya, dan menjadi guru memang bidang yang ditekuni serta sesuai dengan kompetensi keahlian yang dimiliki, maka dari itu guru tersebut memilih untuk tetap menjadi guru kontrak. Ada juga guru yang bertahan menjadi guru kontrak karena memang bercita-cita menjadi guru, serta ada pula yang memiliki harapan besar untuk bisa diangkat menjadi guru tetap di SMK Negeri 3 Singaraja. Alasanalasan inilah yang membuat guru kontrak tersebut tetap bertahan, walaupun kepuasan kerjanya terbilang rendah. 


\section{Simpulan dan saran}

Dapat ditarik kesimpulan dari hasil penelitian dan pembahsan diatas yaitu. 1) Penyebab dari rendahnya kepuasan kerja pada guru kontrak di SMK Negeri 3 Singaraja yaitu disebabkan karena : (1) kurangnya jam mengajar pada guru kontrak, (2) seringnya mengalami keterlambatan pemberian gaji, (3) Mengajar tidak sesuai dengan kompetensi keahlian yang dimiliki. 2) Dampak dari rendahnya kepuasan kerja yang dirasakan oleh guru kontrak di SMK Negeri 3 Singaraja yaitu ada dampak terhadap guru, siswa, dan sekolah. Dimana dampak pada guru adalah: (1) menurunnya semangat mengajar yang dapat membuat rasa malas untuk mengajar, (2) dengan sengaja terlambat datang saat akan mengajar, (3) malas untuk berpartisipasi dalam mengikuti kegiatan yang ada di sekolah. Sedangkan dampak untuk sisawanya yaitu: (1) siswa tidak akan mendapatkan kegiatan belajar yang optimal. Dan kemudian dampak pada sekolah yakni: (1) dapat merusak visi misi dan tujuan sekolah untuk menciptakan lulusan unggul yang berkualitas yang berdya saing tinggi dan siap bekerja, (2) kurangnya minat masyarat pada SMK Negeri 3 Singaraja. 3) Alasan guru kontrak tetap bertahan menjadi guru kontrak di SMK Negeri 3 Singaraja yakni: (1) agar tetap adanya pemasukan untuk guru tersebut untuk mencukupi kebutuhn hidupnya, karena bagi sebagian guru kontrak tersebut tidak ada Igi pekerjaan lain, (2) Ada juga guru yang bertahan menjadi guru kontrak karena memang bercita-cita menjadi guru, (3) memiliki harapan besar untuk bisa diangkat menjadi guru tetap di SMK Negeri 3 Singaraja. Alasan-alasan inilah yang membuat guru kontrak tetap bertahan, walaupun kepuasan kerjanya terbilang rendah.

Adapun saran berdasarkan simpulan diatas maka ditemukan 2 saran yaitu: (1) Bagi SMK Negeri 3 Singaraja, diharapkan agar sekolah lebih memperhatikan lagi kepuasan kerja pada guru, dikarenakan kepuasan kerjanya dapat mempengaruhi pada kinerjanya yang berujung pada tercapainya visi,misi dan tujuan sekolah, (2) Bagi peneliti, bagi Peneliti yang tertarik dan berminat untuk mendalami tentang Rendahnya kepuasan kerja, maka diharapkan untuk mengembangkan penelitian ini dengan menambahkan sampel atau popolasi yang lebih luas agar dapat menguji variable lain yang diduga kuat dapat mempengaruhi kepuasan kerja.

\section{Ucapan terima kasih}

Penulis mengucapkan terima kasih kepada bapak kepala SMK Negeri 3 Singaraja yang telah memberikan izin untuk melakukan penelitian di SMK Negeri 3 Singaraja dengan izin tersebut penulis dapet menyelesaikan penelitian ini Dengan Nomor Surat: 432. 4/221/SMKN.3.SGR/20020

\section{Daftar Pustaka}

Fauzi. 2017. Pengaruh Kompensasi dan Lingkungan Kerja Terhadap Kepuasan Kerja PT Tor Ganda Medan. Jurnal Riset Manajemen \& Bisnis (RJBM), Vol. 2, No.3.

Hasanah. 2015. Faktoe-faktor yang Mempengaruhi Kepuasan Kerja Guru. Jurnal Manajer Pendidikan. Volume 9. No.1.

Hidayat, Syah. 20110. Pengantar Umum Metodologi Penelitian PendekatanVerivikatf. Pekanbaru: Suska Pres.

Indah, Yoanna, Mega, Rosaria. 2010. Analisis Kepuasan Kerja Guru- Guru Sekolah Dasar (SD) Kanisius Yogyakarta. Jurnal Universitas Sanata Dharma Yogyakarta.

Irwani, Teuku. 2017. Kepuasan Kerja Guru Sekolah Dasar Dalam Kecamatan Johan Pahlawan Kabupaten Aceh Barat. Jurnal Bina Gogik. Volume.4, No.2.

Mangkunegara, A.A. Anwar Prabu. 2013. Manajemen Sumber daya Manusia Perusahaan. Bandung: Remaja Rosdakarya.

Mansukra, Aidil. 2017. Analisis Kepuasan kerja Karyawan di PT Perkebunan Nusantara V Kebun Sei Rokan Kecamatan Pagarantapah Darussalam Kabupaten rokan Hulu. Jurnal Agribisnis. Vol.19, No.1. 
Perdani, Priska, Putri. 2010 Analisis Kepuasan Kerja Guru. Tesis Fakultas IImu Sosial dan IImu Politik Departemen IImu Administrasi Program Pascasarjana. Universitas Indonesia.

Puji, Setyosari. 2010. Metoda Penelitian Pendidikan dan Pengembangan.. Jakarta: Kencana.

Rahayuningsih, Sri. 2017. Pengaruh Kompensasi dan Lingkungan Kerja Terhadap Kepuasan Kerja Guru SMP Negeri di Sub Rayon 02 Pacagaan Kabupaten Jepara. Jurnal Universitas PGRI Semarang.

Ramadanita, Raja, Devi.2018. Pengaruh Kompensasi dan Lingkungan Kerja Terhadap Kepuasan Kerja pada PT Suka Fajar Pekanbaru. Jom FISIP. Vol 15, No.1

Rofianda,saifrudin. 2014. Perbedaan akepuasan Kerja Guru yang Telah Bersertifikasi dengan yang Belum Bersertifikasi di Kota Surakarta. Skripsi Fakultas Psikologi. Universitas Muhamadiyah Surakarta.

Siyoto, Sandu. 2015. Dasar Matodologi Penelitian. Yogyakarta : Literasi Media Publishing.

Sutrisno, Edy. 2009. Manajemen Sumber Daya Manusia. Jakarta: Pranada Media Group.

Tukiyo. 2015. Motivasi dan Kepuasan Kerja Guru Sekkolah Dasar di Kabupaten Klaten. Prosiding Seminar nasional Pendidikan. Universitas Sebelas Males Surakarta dan ISPI wilayah Jawa Tengah.

Wibowo, Satrijo, Budi. 2010. Analisis Kepuasan dan Ketidakpuasan Kerja Guru SMA Negeri Kota Madiun. Jurnal FPIPS IKIP PGRI MADIUN. Vol. 10, No. 1. 